\title{
Old French SI, Syntax and Function in Diachrony
}

Wyn Shaw

University of Oxford

wyn.shaw@st-hildas.ox.ac.uk

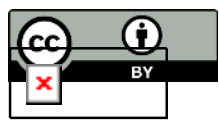

Received: $15-03-21$

Accepted: $30-09-21$

Published: 22-02-22

How to cite: Shaw, Wyn. 2022. Old French SI, Syntax and Function in Diachrony. RLLT17, eds. Ora Matushansky, Laurent Roussarie, Michela Russo, Elena Soare \& Sophie Wauquier. Special issue of Isogloss Open Journal of Romance Linguistics $8(2) / 9,1-18$.

DOI: https://doi.org/10.5565/rev/isogloss.120

\begin{abstract}
This article offers a diachronic analysis of the Old French particle SI. Using data from both verse and prose texts, I analyse the function and syntax of SI from the $12^{\text {th }}$ to $14^{\text {th }}$ centuries. I find that SI fulfills a variety of functions throughout the period, beginning as a subject continuity marker before acquiring functions as a resumptive and an expletive among others. SI's syntax is defined by its proximity to the verb, occupying the specifier of the left-peripheral head which hosts the verb. This head changes through the Old French period from the lower left peripheral head Fin to the higher head Force. These findings are shown to have ramifications for the study of Medieval Romance syntax and discourse particles.
\end{abstract}

Keywords: information structure, si, V2, Old French, left periphery. 


\section{Introduction}

\subsection{Background and Aims}

In this article, I aim to provide a new analysis of the Old French particle SI. By focusing on its unique position at the intersection of discourse pragmatics and left-peripheral syntax, I hope to provide a description of its function and syntax across a wide variety of texts throughout the Old French period. SI is a particle derived from Latin SIC, it is extremely frequent throughout the Old French period, indeed, it "occurs in virtually every French text from the ninth-century [...] through the fourteenth century" (Fleischman, 1992: 434). Although a rich literature already exists on SI, its function and syntax remain heavily debated.

I take a large-scale, quantitative approach to SI, aiming to resolve many of the previous debates around its function and syntax. I focus on testing the popular topic continuity analysis (Fleischman, 1991, 1992, van Reenen \& Schøsler, 2000, Wolfe, 2018b). I argue that SI is a phrasal constituent which occurs immediately preverbally, in the specifier of the head occupied by the verb. With regards to function, I argue that SI fulfills a variety of different functions across different points in the Old French period, including functions as a subject continuity (SC) marker, a resumptive and as a Verb Second (V2) expletive.

\subsection{Structure of the Article}

This article is structured as follows. In section 2, I introduce my theoretical assumptions, particularly focusing on cartographic analyses of the left periphery of the clause. In section 3, I give an overview of the existing literature on SI, discussing analyses both of its function and its syntax. In section 4, I introduce my own methodology, discussing the texts I have selected as well as the data gathering methodology and my approach to data analysis. In section 5, I discuss my findings, both regarding SI's function and its syntax. Finally, in section 6, I give some concluding remarks on possible further directions for future research.

\section{Theoretical Assumptions}

\subsection{Syntax}

Since at least Thurneysen (1892) Old French has been treated as a V2 language. ${ }^{1}$ This is an assumption I will be taking up here. I further assume that the V2 constraint involves movement of the verbal head to the C-domain with the specifier of this head obligatorily filled. However, since Rizzi's (1997) work on the cartography of the clausal left-periphery, the C-domain has been analysed as containing a variety of different sub-domains, thus leading to a more specific V2 analysis. While Rizzi's (1997) original description remains influential, several

1 Thurneysen (1982), Adams (1987), Roberts (1993), Vance (1997), Rouveret (2004), Labelle (2007), Donaldson (2012), Wolfe (2018a,b); pace Rinke \& Meisel (2009), Sitaridou (2012). 
elaborations have been developed. Here I will be specifically using the hierarchy proposed by Ledgeway (2010), shown in (1) (adapted from Wolfe, 2018a:3):

(1) [Frame Hanging Topic, Adv Frame-Setting [Force Comp $_{1}$ [Topic Left Dislocation, Aboutness Topic [Focus Focus Contrastive $_{\text {Quantifier }}$ Indefinite $_{\text {Focus }}$ New Information $_{\text {I }}$ $\left[\right.$ Fin Comp $_{2}[T P$... $\left.\left.\left.\left.\left.]\right]\right]\right]\right]\right]$

Ledgeway's hierarchy itself draws and expands on that of Benincà (2004) and much other work on the left periphery in Romance. While Ledgeway's (2010) hierarchy is the one we shall assume for our discussion of the syntax, much reference will be made to other studies of the left periphery. For example, following Benincà and Poletto (2004), I take List Items (LIs) to lexicalise the lowest position in the Topic field (Benincà and Poletto, 2004:70).

\subsection{Pragmatics}

Ledgeway's (2010) syntactic hierarchy also makes use of several sub-divisions of the topic-focus typology and these concepts are extremely important with regards to the function of SI. As such, I now discuss the definitions of these terms and any further sub-divisions which will be used here. At their core, topics and foci are elements of the discourse distinguished based on their accessibility to discourse participants. Cruschina defines topics and foci as follows: 'topics are [...] considered active (or at least identifiable) while foci express new information' (Cruschina, 2012: 10). Within our syntactic hierarchy two types of further distinctions are made: syntactic distinctions, such as that between Hanging Topics (HT) and Left Dislocated topics (LD) and functional distinctions such as that between Informational Foci (IF) and Contrastive Foci (CF). These topic and focus types, as well as List Items, mentioned above, are illustrated in (2)-(6). In (2), I give an example of a Hanging Topic, identifiable by the following frame-setting subordinate clause, meaning that, in Ledgeway's (2010) hierarchy, this topic must be in Frame and thus a Hanging Topic.

(2) et cil, cum ils les virent, si descendirent de lor chevaus et and those when they them saw sI descended from their horses and alerent encontre

went to.meet

"And those ones, when they saw them, descended from their horses and went to meet them"

Villehardouin's Conqueste de Constantinople $\$ 116$

In (3), I give an example of a Left Dislocated topic, identifiable by the fact that the full PP has been moved, rather than an extracted DP: ${ }^{2}$

(3) De cele estoire si fu chevetaines Johans de Neele

Of this army SI was leader Johans of Neele

"Johans of Neele was the leader of this army"

Villehardouin's Conqueste de Constantinople $\$ 48$

2 See Benincà and Poletto (2004) for details on distinguishing Left Dislocated topics and Hanging Topics. 
In (4) I give an example of an Informational Focus, in this example 'Bengaber' has not been mentioned before in the text and, indeed, is not mentioned again, thus being entirely new information moved to the left periphery as an Informational Focus:

(4) Bengabér en Ramath Galáád si out la cited de Anothiaïr

Bengaber in Ramath Galaad SI had the city of Anothiair

"Bengaber in Ramath Galaad had the city of Anothiair"

Quatre Livres des Reis, p. 65

In (5) I give an example of a Contrastive Focus, distinguished by the fact that Eurus is contrasted against a previous discussion of other winds:

(5) Eurus si feri qui tost les remist a la voie

Eurus SI was who all them put.back to the sail

"It was Eurus who put them all back to sail"

Histoire Ancienne Jusqu’à César $§ 606.7$

Finally, in (6) I give an example of a List Item, where the DP 'Li un des ars' is the first in a list of different arts:

(6) Li uns des ars si fu d' un bois

The first of.the arts SI was of a wood

"The first of the arts was of wood"

Roman de la Rose (First Continuation) 1.910

As well as these distinctions for syntactic analysis, we will use further distinctions for the analysis of the function of SI, discussed in section 4 .

\section{Previous Work on SI}

Having established the theoretical background for this work, I turn to the previous literature on SI. While a wide variety of analyses of SI's function have been proposed $^{3}$ we will be primarily focusing on three analyses here: the topiccontinuity analysis (Fleischman 1991, 1992, van Reenen and Schøsler, 2000, Wolfe, 2018b); the V2 expletive analysis (Ledgeway, 2008) and the resumptive analysis (Meklenborg, 2020). Under the topic continuity analysis, SI is considered a marker of either topic continuity or Subject Continuity. In Fleischman's work the term "same subject" marking is used while in van Reenen and Schøsler's (2000) work the notion of topic continuity is defined as "[a] series of same subjects in main clauses" (van Reenen and Schøsler, 2000: 63). This analysis has been further developed by Wolfe (2018b), who also provides a syntactic analysis of the particle. A substantial proportion of this article is devoted to testing this

$3 \quad$ For early analyses see Foulet (1930), Kibler (1984), Marchello-Nizia (1985) and Stammerjohann (1988). 
analysis. However, we will also be discussing two further analyses. In Ledgeway's (2008) V2 expletive analysis, SI is treated as a filler word, utilised to fulfil the Old French V2 requirement when no other constituent is available. Finally, in Meklenborg's (2020) resumptive analysis, SI is treated as a resumptive of fronted pre-SI material.

I now turn to previous work on the syntax of SI. It has been noted as early as Skårup (1975) that SI occupies a pre-verbal zone, with only clitics and negation intervening between it and the verb. With recent developments in Rizzi's (1997) analysis of the clausal left periphery, attempts have been made to describe the specific syntax of SI with regards to the left periphery. For instance, Wolfe (2018b) argues that, by the $12^{\text {th }}$ century, SI is grammaticalized to be first merged in Spec-Fin (Wolfe, 2018b: 30) while, in the $13^{\text {th }}$ century, the V2 requirement shifts to operate in ForceP and thus, SI is reanalysed to be first-merged in SpecForce (Wolfe, 2018b: 34). Throughout this analysis, SI is treated as a phrasal constituent (see also Benincà, 2004). Meklenborg (2020) provides an alternative analysis of SI in this framework. For Meklenborg (2020), two types of resumptive SI have different syntax. Clausal-resumptive SI is a phrasal constituent occupying the specifier of the head hosting the finite verb, with all pre-SI material simply occupying its regular position in the left periphery. On the other hand, argument/PP/adverb-resumptive SI is a head occurring higher in the left periphery than the verb, with pre-SI constituents occupying the specifier of SI's position. Thus, Meklenborg's (2020) approach in part takes up the analysis of SI as a head as opposed to a phrasal constituent, a view also espoused by Ferraresi and Goldbach (2003) and Ledgeway (2008). Ledgeway's (2008) head-analysis, however, differs from Meklenborg's (2020). Ledgeway (2008) argues, primarily for Old Neapolitan but extending the syntactic analysis to Old Romance in general, that SI occupies the head of Fin, while the verb remains lower in the Tdomain (Ledgeway, 2008: 452). SI's presence in Fin then licenses pre-verbal null subjects, which fill the Spec-Fin slot, leading to the surface V2 often found with SI. Whether or not this analysis is correct for Old Neapolitan, it seems unnecessary for Old French data. For Ledgeway's (2008) account we must stipulate further licensing conditions for null subjects and allow sI to be the only non-verbal head which can be merged in Fin. Given these stipulations, Ledgway's (2008) account seems unlikely to be accurate.

It is clear, then that the function and syntax of SI are heavily debated. It should also be noted that several of these previous works suffer from data issues, with Fleischman $(1991,1992)$ providing no quantitative data and Wolfe (2018b) comparing exclusively verse texts from the $12^{\text {th }}$ century to exclusively prose texts from the $13^{\text {th }}$ century onwards. Thus, by testing these various claims on SI with a considered quantitative approach, I hope to establish consensus on one of the most widespread particles of Old French and thus expand our understanding of Old French syntax and pragmatics more broadly.

\section{Methodology}

I now turn to my own methodology. Utilising the Base de Français Médiéval (BFM) corpus and the work of The Values of French Language and Literature in 
the European Middle Ages project (TVOF) I selected 11 texts from the $12^{\text {th }}-14^{\text {th }}$ centuries. The texts, the abbreviation used for them, whether they are prose or verse, their text-type, their approximate datings (as given by the BFM or TVOF) and their dialect are given in Table 1.

Table 1. List of Primary Sources

\begin{tabular}{|c|c|c|c|c|c|}
\hline Title & Abbreviation & $\begin{array}{l}\text { Verse } \\
\text { Prose }\end{array}$ & $\begin{array}{l}\text { Text } \\
\text { Type }\end{array}$ & Dating & Dialect \\
\hline Eneas & Eneas & Verse & Roman & c. 1155 & Norman \\
\hline Conte du Graal & Graal & Verse & Roman & c. 1185 & Champenois \\
\hline Quatre Livres des Reis & QLR & Prose & Biblical & c. 1190 & $\begin{array}{l}\text { Anglo- } \\
\text { Norman }\end{array}$ \\
\hline $\begin{array}{r}\text { Villehardouin's } \\
\text { Conqueste } \\
\text { de Constantinople }\end{array}$ & Villehardouin & Prose & History & c. 1205 & $\begin{array}{l}\text { Champenois } \\
\text { /Unclear }\end{array}$ \\
\hline $\begin{array}{l}\text { Histoire Ancienne } \\
\text { Jusqu'à César }\end{array}$ & HA & Prose & History & $\begin{array}{r}\text { c. } 1211 \\
-1225\end{array}$ & Parisian \\
\hline $\begin{array}{r}\text { Roman de la Rose (first } \\
\text { continuation) }\end{array}$ & RR1 & Verse & Roman & c. 1225 & Orléanais \\
\hline $\begin{array}{r}\text { Recit d'un Menestrel } \\
\text { de Reims }\end{array}$ & Menestrel & Prose & History & c. 1260 & Champenois \\
\hline $\begin{array}{r}\text { Roman de la Rose } \\
\text { (second continuation) }\end{array}$ & RR2 & Verse & Roman & $\begin{array}{r}\text { c. } 1269 \\
-1278 \\
\end{array}$ & Parisian \\
\hline Roman de Fauvel & Fauvel & Verse & Roman & c. 1310 & Norman \\
\hline $\begin{array}{r}\text { Chartes de l'Abbaye de } \\
\text { Magloire }\end{array}$ & Magloire & Prose & Charters & $\begin{array}{r}\text { c. } 1330 \\
-1345 \\
\end{array}$ & Parisian \\
\hline $\begin{array}{r}\text { Grandes Chroniques } \\
\text { de France IX }\end{array}$ & Chroniques & Prose & History & c. 1340 & Parisian \\
\hline
\end{tabular}

All texts have been taken from the BFM except for the $H A$ for which the TVOF's edition has been used. ${ }^{4}$ I have endeavoured to gather a mixture of both prose and verse texts from across the period being studied, to allow for comparison between the two forms, I have also endeavoured to minimise variation in text-type, with all verse texts being romans and most of the prose texts being histories. Keeping the dialect of the texts homogeneous has been less successful, although there are no texts from the more distinct Walloon, Picard or Burgundian dialects (on which see Dees, 1985, 1990). A central component of the methodology of this paper is a focus on considering elements of variation beyond the diachronic. By performing a continued comparison between verse and prose texts as well as acknowledging the influence that various other factors will have on the language of a text, I hope to avoid the data issues which have been significant in previous works on SI and overcome the verse-prose distinction which Simonenko, Crabbé \& Prévost (2018) show to be significant in linguistic variation in Old French.

Now to the specifics of my methodology. From each text I gathered around 250 examples of SI or as many as could be found in the text, including variant spellings such as $c i, s e, s$ ' etc. I was careful to exclude those uses of sI that had become fully codified and fossilised across all texts such as si dist 'he spoke thus', si comme 'just as', si que 'such that' etc. For each instance of sI I marked the 
relationship of the clause's subject to the previous discourse. Following Fleischman's (1991, 1992) notion of same subject marking and van Reenen and Schøsler's (2000) definition of topic continuity, I have focused on the relation between the subject of main clauses and previous main clauses. For each clause the relationship is marked as one of four types: Subject Continuity (SC), where the subject is the same as the previous main clause; Discourse Subject Switch (DSS), where the subject is different from the previous main clause but has been mentioned in the recent discourse; Old Subject Switch (OSS), where the subject is different from the previous main clause and has not been mentioned in the recent discourse but has been mentioned at some point earlier in the text and finally, New Subject Switch (NSS) where the subject of the clause is entirely new.

To further illustrate this typology of information-structural relationships, I give examples below in (7)-(10). Firstly, an example of Subject Continuity:

il vait avant, si la salue

he goes ahead SI her greets

"He goes ahead and salutes her"

Eneas 1. 722

We see in (7), that the subject of both clauses is shared, an example of Subject Continuity. Secondly, an example of Discourse Subject Switch:

\author{
Quant li rois 1' oi, si saut \\ When the king it heard SI jumped \\ "When the king heard this, he jumped" \\ Menestrel p. 3
}

While, in (8), the king has been mentioned immediately before the main clause, it is in a subordinate clause, not the previous main clause. Thus, this is a case of Discourse Subject Switch. Next, an example of Old Subject Switch:

$$
\begin{aligned}
& \text { si n' i feist riens Avarice } \\
& \text { SI NEG } i \text { did anything Avarice } \\
& \text { "Avarice did not do anything" } \\
& \text { RR1 1. } 296
\end{aligned}
$$

In (9), Avarice was not the subject of the preceding main clause and, in addition, has not been mentioned for several clauses (about 70 lines) and thus this is taken as a case of Old Subject Switch. Finally, an example of New Subject Switch:

(10) Li dux de Venise, qui ot a nom Henris Dandole, et ere mult sages The duke of Venice who had as name Henry Dandole and was very wise et mult prouz, si les honora mult and very brave SI them honored much "The duke of Venice, who was called Henry Dandole and was very wise and very brave, honored them greatly" Villehardouin $§ 15$ 
While I have not provided the preceding clause in this example, this is the first mention of the duke of Venice. This clause introduces the character into the text. As such, this is a clear case of New Subject Switch.

Additionally, I made note of any material preceding SI in a clause as well as any material intervening between SI and the verb. Finally, I noted the frequency of SI in each text per thousand words.

\section{Findings}

I now present my data and findings on SI. I begin by discussing the function of SI across the texts studied before discussing its syntax.

\subsection{Function}

\subsubsection{Subject Continuity}

With regards to function, I first attempted to test the Subject Continuity analysis of SI across the texts. The data regarding Subject Continuity are given in Table 2:

Table 2. SI and Information Structure-types across texts

\begin{tabular}{|r|c|c|c|c|c|c|}
\hline Texts & SC (\%) & DSS (\%) & OSS (\%) & NSS (\%) & Expl (\%) & Total (\%) \\
\hline 12 $^{\text {th }}$ century & & & & & & \\
\hline Eneas & $139(71.3)$ & $37(19.0)$ & $8(4.1)$ & $7(3.6)$ & $4(2.0)$ & $195(100)$ \\
\hline Graal & $184(70.8)$ & $49(18.8)$ & $12(4.6)$ & $8(3.1)$ & $7(2.7)$ & $260(100)$ \\
\hline QLR & $186(75.0)$ & $41(16.5)$ & $10(4.1)$ & $6(2.4)$ & $5(2.0)$ & $248(100)$ \\
\hline 13 $^{\text {th }}$ century & & & & & & \\
\hline Villehardouin & $127(50.4)$ & $81(32.2)$ & $22(8.7)$ & $18(7.1)$ & $4(1.6)$ & $252(100)$ \\
\hline HA & $189(78.7)$ & $27(11.3)$ & $8(3.3)$ & $11(4.6)$ & $5(2.1)$ & $240(100)$ \\
\hline RR1 & $109(62.6)$ & $28(16.1)$ & $20(11.5)$ & $5(2.9)$ & $12(6.9)$ & $174(100)$ \\
\hline Menestrel & $82(33.2)$ & $145(58.7)$ & $7(2.8)$ & $1(0.4)$ & $12(4.9)$ & $247(100)$ \\
\hline RR2 & $122(47.7)$ & $65(25.4)$ & $28(10.9)$ & $19(7.4)$ & $22(8.6)$ & $256(100)$ \\
\hline $\mathbf{1 4}^{\text {th }}$ century & & & & & & \\
\hline Fauvel & $20(40.6)$ & $16(21.6)$ & $12(16.2)$ & $12(16.2)$ & $4(5.4)$ & $74(100)$ \\
\hline Chroniques & $12(20.7)$ & $26(44.8)$ & $7(12.1)$ & $10(17.2)$ & $3(5.2)$ & $58(100)$ \\
\hline
\end{tabular}

It is clear from the data in Table 2 that Subject Continuity is the primary function of SI in the $12^{\text {th }}$ century, although even at this stage it is not categorical. Additionally, the higher frequency of Discourse Subject Switch clauses compared to Old Subject Switch, New Subject Switch and Expletive clauses suggests that perhaps a more general topic-continuity marking function is at play rather than, or in addition to, the narrow Subject Continuity function. In the $13^{\text {th }}$ century, across all text types and across the verse-prose distinction, the Subject Continuity function declines. Si's frequency, however, remains high, indeed often higher than $12^{\text {th }}$ century texts. For instance, in Menestrel SI has a frequency of 76 per thousand words, compared to 39 in Eneas and 43 in $Q L R$. This sustained or even increased frequency suggests that SI must still have some function.

\subsubsection{Resumption}


To account for the sustained frequency of SI, I suggest that the $13^{\text {th }}$ century sees the development of a variety of secondary functions. One of the clearest examples of this is the resumptive function of SI, as proposed by Meklenborg (2020). In Meklenborg's (2020) analysis, SI functions as a resumptive of fronted leftperipheral material. An example of this function is given below in (11), with SI acting as a resumptive of the subject of the fronted temporal quant-clause.

Quant li rois 1' oi, si saut

When the king it heard SI jumped

"When the king heard this, he jumped"

Menestrel p. 3

As this example illustrates, resumptive SI will necessarily be preceded by the fronted material which it is resuming. If resumptive SI is in competition with the Subject Continuity function of SI, we would expect pre-SI material to be more common in those texts with lower rates of Subject Continuity SI. The data on this relationship are given in Table 3:

Table 3. Pre-SI material and non-SC clauses

\begin{tabular}{|r|c|c|}
\hline Texts & Pre-SI Material (\%) & Of which non-SC (\%) \\
\hline $\mathbf{1 2}^{\text {th }}$ century & & \\
\hline Eneas & $36(18.4)$ & $20(55.5)$ \\
\hline Graal & $36(13.8)$ & $22(61.1)$ \\
\hline QLR & $25(10.0)$ & $16(64.0)$ \\
\hline $\mathbf{1 3}^{\text {th }}$ century & & \\
\hline Villehardouin & $110(43.7)$ & $91(82.7)$ \\
\hline HA & $16(6.6)$ & $15(93.8)$ \\
\hline RR1 & $15(8.6)$ & $9(60.0)$ \\
\hline Menestrel & $137(55.2)$ & $126(92.0)$ \\
\hline RR2 & $36(14.1)$ & $18(50.0)$ \\
\hline $\mathbf{1 4}^{\text {th }}$ century & & \\
\hline Fauvel & $31(41.9)$ & $27(87.0)$ \\
\hline Chroniques & $3(5.2)$ & $2(66.7)$ \\
\hline
\end{tabular}

Some of the texts with the lowest rates of Subject Continuity SI such as Villehardouin and Menestrel show some of the highest rates of pre-SI material. Additionally, in these texts, those clauses in which pre-SI material occurs are overwhelmingly non-Subject Continuity clauses. This suggests two primary competing functions of SI in this period: Subject Continuity marking and resumption.

\subsubsection{Other Functions}

While this analysis does prove extremely useful for accounting for sI's complex distribution, some texts remain anomalous. For instance, the two continuations of the Roman de la Rose, Magloire and Chroniques do not have high rates of Subject Continuity SI, nor high rates of pre-SI content, suggesting neither function. We might account for the maintained use of SI in these texts as an example of the V2expletive function, as described by Ledgeway (2008) and Wolfe (2018b). With all other functions bleached, SI begins to act as a simple last resort to fulfill the V2 
requirement. This is particularly convincing in the verse texts such as the Roman de la Rose since expletives could also be used to fulfill metric requirements. In addition to this expletive function, SI is used in a variety of fixed expressions such as si dist 'He spoke thus' si avint 'It happened thus' si est-ce que 'So it is that'. An example of this kind of function is given below in example (12):

É puis úrad Anna, si dist and then heard Anna si said "and then he heard Anna and spoke thus" QLR p. 3

Indeed, while SI survives in later centuries, dying out only in the $17^{\text {th }}$, its frequency is very low and almost exclusively in set expressions of this kind. For instance, several examples of the phrase si est-ce que... can be found in Rabelais. ${ }^{5}$

\subsubsection{Interim Summary}

In summary, SI's function varies considerably across the history of its use. In the $12^{\text {th }}$ century, the Subject Continuity function of SI is standard, although not categorical. In the $13^{\text {th }}$ century, the Subject Continuity function survives in some texts (e.g. the $H A$ ) while a resumptive function develops in others (e.g. Menestrel) and in others all pragmatic function seems to be bleached, with SI acting as an expletive fulfilling the requirements of the V2 constraint. In the $14^{\text {th }}$ century, this V2 expletive function is maintained in some texts but in others SI's frequency drops considerably, now only found in fixed expressions until it stops being used entirely in the $17^{\text {th }}$ century.

\subsection{Syntax}

Now that I have provided my analysis of si's function, I turn to its syntax. I firstly discuss its status as a head or phrasal constituent before turning to the position which it occupies in the left periphery and what this can tell us about the V2 constraint in Old French.

\subsubsection{SI and the Verb}

There has been some debate as to SI's status as a head (see Ferraresi and Goldbach, 2003: 111, Ledgeway, 2008, Meklenborg, 2020) or phrasal constituent (see Adams, 1987, Vance, 1995: 184-185, Vance, 1997: 53, Benincà, 2004, Wolfe, 2018b). I argue here for the analysis of SI as a phrasal constituent. In our data, SI is almost always directly adjacent to the verb, with only clitics, such as object and negation clitics, intervening. This observation holds across most of the texts in my sample, with only 8 extremely marginal counter-examples out of our 2016 clauses, potentially simply scribal errors. An example of an intervening clitic is given below in (13):

(13) Et si les ocesimes

and si them killed

"And we killed them"

$5 \quad$ e.g. Quart Livre de Pantagruel chapter 2. 


\section{HA $§ 591.14$}

This evidence suggests that SI is deeply connected to the verbal complex. In a head analysis, we would expect that other content would intervene between SI and the verb in the intermediary specifier position or that SI would not fulfil the V2 requirement and material would regularly precede it. Examples of non-clitic intervening material are extremely marginal in our data. Additionally, even in texts with resumptive SI, less than $60 \%$ of clauses feature pre-SI material. The remaining $40 \%$ would have to be considered verb-initial if SI is taken as a clitic. However, verb-initial clauses are extremely rare in Old French (Vance, 1997: 3738). As such, I reject the head analyses of Ferraresi and Goldbach (2003), Ledgeway (2008) and Meklenborg (2020). Instead, I side here with the phrasal analysis of Wolfe (2018b) and Benincà (2004) and interpret SI as a phrasal constituent in the specifier of the head hosting the verb in the left periphery.

\subsubsection{Pre-SI Material}

With SI's phrasal status established, as well as its relation to the verb, I turn to those cases of material preceding SI. In order to analyse SI's position, we turn to our map of the left periphery, laid out above in (1) and given again in (14):

(14) [Frame Hanging Topic, Adv ${ }_{\text {Frame-Setting }}$ [Force $_{\text {Comp }}$ [Topic $_{\text {Teft Dislocation, }}$ Aboutness Topic [Focus Focus Contrastive Quantifier Indefinite Focus Few Information $_{\text {I }}$ $\left[\right.$ Fin Comp $\left.\left.\left.\left.\left._{2}[T P \ldots]\right]\right]\right]\right]\right]$

In order to examine sI's position in the left periphery, I analyse which of the elements shown above can precede SI in a given text. I present the data on preSI material across my texts in Table 4:

Table 4. Pre-SI Material Across Texts

\begin{tabular}{|r|c|c|c|c|c|c|}
\hline Text & Adverb & Frame-Setter & HT & LD & LI & Focus \\
\hline $\mathbf{1 2}^{\text {th }}$ century & & & & & & \\
\hline Eneas & $\checkmark$ & $\checkmark$ & $?$ & $\checkmark$ & $\checkmark$ & $?$ \\
\hline Graal & $\checkmark$ & $\checkmark$ & $?$ & $?$ & X & $\checkmark$ \\
\hline QLR & $\checkmark$ & $\checkmark$ & $?$ & $\checkmark$ & X & $\checkmark$ \\
\hline $\mathbf{1 3}^{\text {th }}$ century & & & & & & \\
\hline Villehardouin $^{\text {Hile }}$ & $\checkmark$ & $\checkmark$ & $\checkmark$ & $\checkmark$ & X & $?$ \\
\hline HA & $\checkmark$ & $\checkmark$ & $?$ & $\checkmark$ & $\checkmark$ & $\checkmark$ \\
\hline RR1 & $\checkmark$ & $\checkmark$ & $?$ & $?$ & $\checkmark$ & $\checkmark$ \\
\hline Menestrel & $\checkmark$ & $\checkmark$ & $?$ & $?$ & X & X \\
\hline RR2 & $\checkmark$ & $\checkmark$ & $\checkmark$ & $?$ & X & $\checkmark$ \\
\hline $\mathbf{1 4}^{\text {th }}$ century & & & & & & \\
\hline Fauvel & $\checkmark$ & $\checkmark$ & $?$ & $\checkmark$ & $\checkmark$ & $?$ \\
\hline Chroniques & X & $\checkmark$ & X & X & X & X \\
\hline
\end{tabular}

It is important to note the difficulty in disambiguating Hanging Topics and Left Dislocated topics. The only fail-safe means of disambiguating are the movement of a full PP to the left periphery, which is an indicator of a Left 
Dislocated topic (Steiner, 2014: 41, Benincà and Poletto, 2004: 13-14) and the relative ordering of left-peripheral elements, with Hanging Topics preceding adverbs and frame-setters and Left Dislocated topics following. ${ }^{6}$ Thus, cases where only ambiguous Hanging Topics and Left Dislocated topics are found are marked with a question mark in both columns. Likewise, texts where only one or two foci are found, and they could be interpreted as topics, are marked with a question mark.

The key to analysing these data is to examine the last three columns. If a text has confirmed cases of Left Dislocated topics, List Items or foci, V2 cannot be operative in Force, since these items occur below Force. Several texts show pre-SI foci, which suggest a Fin-V2 analysis, since Fin is the only domain below Focus. Thus, it is probably the case that all texts with any constituents lower than Force fronted before SI are enacting a Fin-V2 system.

Once we consider the verse-prose distinction the patterns of variation become clearer. The two texts which do not seem to have Fin-V2 operative are the two latest prose texts: Menestrel and Chroniques. Thus, following Wolfe (2018a,b) and Rouveret (2004), I suggest that the V2 grammar of Old French shifts during the $13^{\text {th }}$ century, from Fin-V2 to Force-V2. This shift only occurs in prose texts, while verse texts maintain the more archaic and less syntactically restrictive Fin-V2. This view of a conservative $13^{\text {th }}$ century verse grammar is also supported by Roberts (1993: 135-136) as well as Simonenko, Crabbé and Prévost's (2018) work on delayed syntactic changes in Old French verse texts.

To illustrate my analysis, I provide examples from several texts, demonstrating the V2-type operative in each period. I begin with the $12^{\text {th }}$-century texts. As shown in Table 4, all texts have pre-SI frame-setters and adverbials. It should be noted that adverbials can co-occur with each other and with framesetters, suggesting further internal ordering within the Frame slot. Examples of quant-clauses and adverbials in $12^{\text {th }}$-century texts are given below in (15)-(16):

(15) Puis si se asis

Then SI REFL sat.down

"Then he sat down"

QLR p. 62

(16) Quant vint a l' avesprer del jor, si s'en retorna Eneas

When came to the evening of.the day SI REFL.PART returned Eneas

"When it came to the evening of the day, Eneas returned"

Eneas 11. 8900-8901

We now turn to the left-peripheral DPs in $12^{\text {th }}$-century texts. Numerous examples of left peripheral topics can be found in $12^{\text {th }}$-century texts, as shown below in (17) from $Q L R$ :

(17) É nus si curumes al sud de la cuntréé de Cerethi and we SIran to.the south of the country of Cerethi

$6 \quad$ Even this is not fully unambiguous, for example, Benincà and Poletto (2004:20) also provide a lower left-peripheral adverbial position. 
"and we ran to the south of the country of Cerethi"

QLR p. 32

While (17) could be either a Hanging Topic or a Left Dislocated topic, Eneas has examples of clear Left Dislocated topics. An example is given in (18), the fact that the topic is a full PP shows that it must be a Left Dislocated topic:

$$
\begin{aligned}
& \text { a lui si tret } \\
& \text { at him si shot } \\
& \text { "He shot at him" } \\
& \text { Eneas } 1.5428
\end{aligned}
$$

This excludes the Topic field as the locus of $\mathrm{V} 2$ in $12^{\text {th }}$-century texts. We also find foci in some $12^{\text {th }}$-century texts: Graal and $Q L R$. Examples are given below in (19) and (20):

(19) et sa char si fu dehachiee de noif de gresle et de gelee and her flesh SI was scratched by snow by hail and by ice "and her flesh was scratched by snow, by hail and by ice" Graal 11. 3712-3713

(20) Bengabér en Ramath Galáád si out la cited de Anothiaïr Bengaber in Ramath Galaad SI had the city of Anothiair "Bengaber in Ramath Galaad had the city of Anothiair" Quatre Livres des Reis, p. 65

In both these examples, the leftward-moved DPs are informationally new, totally unmentioned in the preceding text and thus are treated here as Informational Foci. Thus, in both $Q L R$ and Graal, SI and the verb must occupy Fin, since all higher left peripheral areas have been ruled out. While Eneas lacks an example of a pre-SI focus, we do have an example of a Left Dislocated topic, given above, excluding the Force field. Thus, given the corroborating data from the other $12^{\text {th }}$-century texts, this suggests that Eneas too enacts Fin-V2. To further illustrate this analysis, I provide a bracketing of example (18) below in (21):

[Frame $[$ Force $[$ Topic a lui $[$ Focus $[$ FinP si [Fin' [Fin tret $][$ TP ... $]]]]]]$ Eneas 1. 5428

I next turn to the $13^{\text {th }}$ - and $14^{\text {th }}$-century texts which seem to enact Fin-V2: two prose texts: Villehardouin and the $H A$ and the verse texts: RRl, RR2 and Fauvel. Adverbials and frame-setters are found in all these texts. However, of most interest to us are those elements which exclude Force, suggesting that V2 operates in Fin. Thus, I present here an example of a Left Dislocated topic PP in Villehardouin, a Contrastive Focus in the $H A$, an Informational Focus in $R R 2$ and a List Item in Fauvel suggesting the Fin-V2 analysis for all these texts.

(22) De cele estoire si fu chevetaines Johans de Neele

Of this army SI was leader Johans of Neele 
"Johans of Neele was the leader of this army"

Villehardouin's Conqueste de Constantinople $§ 48$

(23) Eurus si feri qui tost les remist a la voie

Eurus SI was who all them put back to the sail

"It was Eurus who put them all back to sail"

Histoire Ancienne Jusqu'à César $§ 606.7$

(24) car Juvenaus si nous raconte...

because Juvenal SI us tells...

"Because Juvenal tells us..."

RR2 1. 8257

(25) Mon droit nom si est Providence

My right name SI is Providence

"My true name is Providence"

Fauvel 1. 2261

In (22), the full PP shows that this is a Left Dislocated topic. In (23), Eurus is being referred to contrastively from preceding discussion of 'the winds' more generally, and thus is an example of Contrastive Focus. (24) shows an example of an Informational Focus, with this being the first mention of Juvenal in the text. Finally, (25) shows a case of a List Item preceding SI, with Providence listing their true names. These examples exclude the Topic and Focus fields as the position of the verb for these texts, suggesting that they too enact Fin-V2.

I next turn to the late $13^{\text {th }}$-century and $14^{\text {th }}$-century prose texts, where a notable shift can be seen. Menestrel has no clear cases of any lower left-peripheral material, with only clear adverbs and frame-setters. Even more extreme, Chroniques only shows Frame-Setters pre-SI, although the sparse data for Chroniques may contribute here. Menestrel does have two examples of ambiguous left-peripheral topics, one of which is given below:

$$
\begin{aligned}
& \text { et il si avoit } \\
& \text { and he si had } \\
& \text { "And he had it" } \\
& \text { Menestrel p. } 14
\end{aligned}
$$

While this example could be either a Hanging Topic or Left Dislocated topic, the rarity of such examples, as well as the total lack of any clear examples of Left Dislocated topics, List Items or Foci, suggests that this is a Hanging Topic. As such, Menestrel is likely to be enacting a stricter V2 higher in the left periphery. The V2 system of the Chroniques also appears to be much stricter than that of the earlier texts. As such I suggest that both these texts are in fact enacting the stricter Force-V2 and that those rare cases of left-peripheral topics in Menestrel are Hanging Topics. To illustrate, I provide a bracketing of example (26) below in (27), et is not represented since I take it to be extra-clausal:

[Frame il [ForceP Si [Force' [Force avoit] [Topic $[$ Focus $[$ Fin $[$ TP ... $]]]]]]$ Menestrel p. 14 
In summary, it seems clear that the $12^{\text {th }}$-century and early $13^{\text {th }}$-century texts enact a Fin-V2 system, since all forms of left-peripheral content can precede SI and the verb. At some point in the $13^{\text {th }}$ century, in prose texts, this system seems to become stricter, with Menestrel and Chroniques enacting Force-V2. Further data from both Menestrel and other later $13^{\text {th }}$ century prose texts would be necessary to completely confirm this view but it is in line with findings from Rouveret (2004) and Wolfe (2018a,b). ${ }^{7}$

\section{Concluding Remarks}

In this study, we have found that the history of the Old French particle SI is complex. In the $12^{\text {th }}$ century, it primarily functions as a Subject Continuity marker, in line with Fleischman's $(1991,1992)$ classic analysis. Throughout this period, SI occupies the specifier of Fin while the verbal head occupies the Fin head. While the mono-functional Subject Continuity analysis seems to apply in $12^{\text {th }}$-century data and some $13^{\text {th }}$-century texts such as the $H A$, I have found that the complexity of most $13^{\text {th }}$-century data is best handled by considering other functions of SI. Taking up Meklenborg's (2020) analysis of SI as a resumptive, I have argued that the $13^{\text {th }}$ century does not simply see a loss of SI's Subject Continuity marking function, as claimed by Wolfe (2018b), but rather the development of secondary functions, amongst which the resumptive function is primary. The use of these functions varies idiosyncratically between different texts, even those of the same text-type and time. By the end of the $13^{\text {th }}$ century, prose texts shift to a stricter Force-V2 and the frequency of resumptive SI reduces, with SI taking up a V2 expletive function, as argued for by Fleischman (1991, 1992), Ledgeway (2008) and Wolfe (2018b). While the loss of SI is not shown in our data, it appears to continue to exist with a variety of rare, conventionalised functions, before its loss in the $17^{\text {th }}$ century.

Finally, I suggest some further directions for study. I have focused here on SI's use as an Subject Continuity marker, however, an in-depth qualitative analysis of SI's other functions in the $13^{\text {th }}$ century, as well as examining how these functions develop from each other would be of great use in examining how pragmatic markers evolve over time. Another potential further direction for research is comparative work on reflexes of Latin SIC across the Romance languages. Meklenborg (2020) finds SI in Old Occitan marks topic switch, as well as acting as a resumptive, while Ledgeway (2008) finds SI marks topic continuity and acts as an expletive in Old Neapolitan. Finally, Poletto (2005) finds SI to be an expletive in Old Italian and shows that it can still occur lower in the clause. Comparative analyses of these cognates of Old French SI and variation in their information-structural function and syntax may allow us to further understand the origins of SI and its development and loss across Romance. Additionally, given

$7 \quad$ See also Labelle (2018: 276-7) and Zaring (2018: 300) on shifting V2 restrictions; Labelle (2007) on embedded clause shifts in 13th century Old French and Poletto (2002) on cross-linguistic data on "high" and "low" V2 in Raeto-Romance. 
the oft-attested expletive function of SI, such an approach would be of great use for an analysis of the V2 phenomenon across the Romance languages.

\section{References}

Adams, Marianne. 1987. "From Old French to the theory of pro-drop". In NaturalLanguage \& Linguistic Theory 5.1: 1-32. https://doi.org/10.1007/bf00161866

Benincà, Paola. 2004. "The Left Periphery of Medieval Romance". In Studi Linguistici e Filologici Online. Rivista Telemantica del Deipartimento di Linguistica dell'Universita di Pisa: 243-297.

Benincà, Paola and Cecilia Poletto. 2004. "Topic, Focus and V2: defining the CP sublayers". In L. Rizzi (ed.), The Structure of CP and IP. The Cartography of Syntactic Structures vol. 2, 52-76. Oxford: Oxford University Press.

Cruschina, Silvio. 2012. Discourse-related features and functional projections. Oxford: Oxford University Press. https://doi.org/10.1093/acprof:oso/9780199759613.001.0001

Dees, A. 1985. Dialectes et scriptae à l'époque de l'ancien français. In Revue de Linguistique Romane, 49: 87-117.

Dees, A. 1990. Towards a dialectology of spoken Old French: the analysis of rhymes. In J. Fisiake (ed.) Historical Linguistics and Philology, 119-134. Berlin: De Gruyter. https://doi.org/10.1515/9783110847260.119

Donaldson, Bryan, 2012. "Initial subordinate clauses in Old French: Syntactic variation and the clausal left periphery". In Lingua 122.9: 1021-1046. https://doi.org/10.1016/j.lingua.2012.04.003

Ferraresi, Gisella and Maria Goldbach. 2003. "Particles and sentence structure, a historical perspective". In U. Junghanns \& L. Szucisch (eds.), Syntactic structures and morphological information, 101-128. Berlin: Walter de Gruyter. https://doi.org/10.1515/9783110904758.101

Fleischman, Suzanne. 1991. "Discourse Pragmatics and the Grammar of Old French: A Functional Reinterpretation of 'si' and the Personal Pronouns". In Romance Philology 44.2: 251-283.

Fleischman, Suzanne. 1992. "Discourse and diachrony: The rise and fall of Old French SI". In M. Gerritsen and D. Stein (eds.) Internal and external factors in syntactic change, 433-474. Berlin: Walter de Gruyter. https://doi.org/10.1515/9783110886047.433

Foulet, Lucien. 1930. Petite syntaxe de l'ancien français. Paris: H. Champion 
Kibler, W. W. 1984. An Introduction to Old French. New York, NY: Modern Language Association of America.

Labelle, Marie. 2007. "Clausal architecture in early Old French". In Lingua 117.1: 289-316. https://doi.org/10.1016/j.lingua.2006.01.004

Labelle, Marie \& Paul Hirschbühler. 2018. "Topic and focus in Old French V1 and V2 Structures". In Canadian Journal of Linguistics/Revue candienne de linguistique 63.2: 264-287. https://doi.org/10.1017/cnj.2017.52

Ledgeway, Adam. 2008. "Satisfying V2 in early Romance: merge vs. move". In Journal of Linguistics 44.2: 437-470. https://doi.org/10.1017/s0022226708005173

Ledgeway, Adam. 2010. "Introduction: The clausal domain: CP structure and the left periphery”. In A. Ledgeway, R. Alessandro \& I. Roberts (eds.), Syntactic Variation: The Dialects of Italy 38-52. Cambridge: Cambridge University Press. https://doi.org/10.1515/zrp-2013-0134

Marchello-Nizia, Christiane. 1985. Dire le vrai: l'adverbe 'si' en français medieval: essai de linguistique historique. Geneva: Droz. https://doi.org/10.2307/2852597

Meklenborg, Christine. 2020. "Resumptive Structures in Gallo-Romance Perspective". In S. Wolfe \& M. Maiden (eds.) Variation and Change in Gallo-Romance Grammar 41-70, Oxford: Oxford University Press. https://doi.org/10.1093/oso/9780198840176.003.0003

Poletto, Cecilia. 2002. "The left-periphery of V2 Rhaeto-romance dialects: A new view on V2 and V3". In S. Barbiers, L. Cornips and S. van der Kleij (eds.), Syntacic Microvariation. Electronic publications of Meertens Instituut.

Poletto, Cecilia. 2005. "'Si' and 'e' as CP Expletives in Old Italian". In M. Batllori, M. L. Hernanz. C. Picallo \& F. Roca (eds.), Grammaticalization and parametric variation 206-235. Oxford: Oxford University Press. https://doi.org/10.1093/acprof:oso/9780199272129.003.0013

Rinke, Esther \& Jürgen M. Meisel. 2009. "Subject-inversion in Old French: Syntax and Information Structure". In Proceedings of the Workshop "Null-subjects, expletives and locatives in Romance". 123: 93-130.

Rizzi, Luigi. 1997. "The Fine Structure of the Left periphery". In L. Haegeman (ed.) Elements of Grammar 281-337. Berlin: Springer Science \& Business Media.

Roberts, Ian. 1993. Verbs and diachronic syntax: A comparative history of English and French. Berlin: Springer Science and Business Media. 
https://doi.org/10.1007/978-94-011-2910-7

Rouveret, Alain. 2004. "Les clitiques pronominaux et la périphérie gauche en ancien français". In Bulletin de la Société de Linguistique de Paris 99.1: 181-237. https://doi.org/10.2143/bsl.99.1.541914

Simonenko, Alexandra, Benoît Crabbé \& Sophie Prévost. 2018. "Text form and grammatical changes in Medieval French: a treebank-based diachronic study". In Diachronica 35.3: 393-428. https://doi.org/10.1075/dia.00008.sim

Sitaridou, Ioanna. 2012. "A comparative study of word order in Old Romance". In Folia Linguistica 46.2: 553-604. https://doi.org/10.1515/flin.2012.019

Skårup, Povl. 1975. Les premières zones de la proposition en ancien français. Copenhagen: Akademisk Forlag.

Stammerjohann, Harro. 1988. "Hiérarchie des connecteurs dans la Chanson de Roland". In H. Nølke (ed.) Opérateurs syntaxiques et cohésion discursive 63-74. Copenhagen: Nyt Nordisk Forlag.

Thurneysen, R. 1892. "Die Stellung des Verbums in Altfranzösischen". In Zeitschrift für Romanische Philologie 16: 289-307. https://doi.org/10.1515/zrph.1892.16.1-4.289

Vance, Barbara S. 1995. "On the Decline of Verb Movement to Comp in Old and MiddleFrench". In A. Battye and I. Roberts Clause Structure and Language Change, 173-199. Oxford: Oxford University Press.

Vance, Barbara S. 1997. Syntactic change in medieval French: Verb-second and null subjects. Berlin: Springer Science \& Business Media. https://doi.org/10.1075/dia.16.2.15sch

Wolfe, Sam. 2018a. Verb Second in Medieval Romance. Oxford: Oxford University Press.

Wolfe, Sam, 2018b. "Probing the Syntax of a Problematic Particle: Old French 'si' Revisited". In Transactions of the Philological Society 116.3: 332-362. https://doi.org/10.1111/1467-968x.12123

Zaring, Laurie. 2018. "The nature of V2 in Old French: Evidence from subject inversion in embedded clauses". In Canadian Journal of Linguistics/Revue Canadienne de linguistique 63.2: 228-308. https://doi.org/10.1017/cnj.2017.50 